\title{
Process approach to organization of wild processing business
}

\author{
Galina Sergeevna Bondareva, and Nikolay Sergeevich Bondarev \\ FSBEI HE Kuzbass State Agricultural Academy, 650056, Markovtseva st., 5, Kemerovo, Russia
}

\begin{abstract}
The study examines the organization of a new business for the harvesting and processing of wild plants based on the development of traditional industries, trades and crafts of rural residents. As process solutions, a block of design justifications is presented, aimed at developing practical measures on the stated topic. In particular, the emphasis is placed on the economic justification and social significance when organizing a business for processing wild plants. In the substantive part of the study, a model for calculating capital investments is presented; sources of financing for a business project are indicated. Separately, it is worth highlighting the element of practical implementation, including the technical modernization of the production process of processing raw materials, namely, the improvement of the technological process through the use of microwave vacuum drying technology. The calculation of the need for personnel is performed; the possible qualification requirements for employees are indicated. The research of the market of similar products based on information search was carried out. An overview of the average retail prices is made according to the Internet portal "Russian agro-industrial server Agroserver.ru", on the basis of which the forecasted amounts of proceeds from sales and the expected profit from organizing a business for processing wild plants are calculated. Significant expected results are: an increase in the standard of living of the population collecting and harvesting wild plants; providing employment in rural areas; saturation of the market with products of wild plants; strengthening of competitive positions; saturation of the market with locally produced products; increasing the profitability of regional and local budgets. It is assumed that at the initial stage, the manufactured products will be sold mainly in the region. The sale will be carried out through trade networks, as well as in markets, stationary retail outlets, fairs, exhibitions, the main consumers of the products will be the population of the Kemerovo region.
\end{abstract}

\section{Introduction}

Recently, there has been great interest and a high level of demand for environmentally friendly products such as mushrooms, berries, medicinal herbs $[1 ; 5 ; 10]$. Due to the changing lifestyle of people, the popularity of this type of product is growing at an enormous pace.

Wild plants are understood to be renewable, natural, environmentally friendly natural products: herbs, mushrooms, berries $[5 ; 10]$. It should be noted that such products have no 
substitutes and have a fairly wide consumer demand, especially recently, due to the increased consumer demand for natural, environmentally friendly healthy food products [9; 12].

The scope of activities of the enterprises proposed for the organization: harvesting of natural non-woody plant raw materials (wild plants), preparing it for sale, subsequent processing and sale of wild plants and products of their processing to the end consumer.

As a result of the implementation of proposals for organizing a business for the processing of wild plants, it is planned to provide residents of the Kemerovo region, a number of regions of the Russian Federation and Siberia with high-quality competitive products of wild plants; ensuring employment of the rural population and, as a consequence, improving the quality of their life.

It is assumed that at the initial stage, the manufactured products will be sold mainly in the region. The sale will be carried out through trade networks, as well as in markets, stationary retail outlets, fairs, exhibitions, the main consumers of the products will be the population of the Kemerovo region.

\section{Materials and Methods}

To achieve the objectives of the study, the organization of business processes is presented on the basis of a process approach; all production is presented and described in the form of separate processes and stages. The theoretical provisions are based on the use of the monographic method, systematization, analysis of information; business economics is calculated based on the methods of economic and financial analysis, the forecast sales plan is built on the basis of expert judgment. Reflection of the final conclusions is based on an abstract-logical research method.

\section{Results}

This section proposes to consider the organization of business in key areas.

First of all, the organization of any business requires financial resources. To achieve the set goals, it is necessary to carry out technical modernization of the production process [8], to ensure its rhythm, to provide a quality component of manufactured products that is competitive in the market (local and external) not only in price, but also in quality.

It should be noted that there is a steady and growing demand for natural, and especially for organic food.

To carry out production for processing wild plants using microwave vacuum drying technology, the enterprise will need the following capital investments (Table 1):

Table 1. Model for calculating capital investments.

\begin{tabular}{|l|l|}
\hline \multicolumn{1}{|c|}{ Category of costs } & \multicolumn{1}{|c|}{$\begin{array}{c}\text { Average cost, } \\
\text { rub. }\end{array}$} \\
\hline $\begin{array}{l}\text { Purchase, installation, adjustment of production equipment (microwave vacuum } \\
\text { drying plant of the series "Monsoon") }\end{array}$ & 550000 \\
\hline Vacuum packing machine & 10000 \\
\hline Certification & 50000 \\
\hline Rent & 60000 \\
\hline Warehouse equipment & 20000 \\
\hline $\begin{array}{l}\text { Other expenses (packing materials - containers, special clothes, stationery, } \\
\text { communication) }\end{array}$ & 40000 \\
\hline Brand development and marketing strategy & 20000 \\
\hline Total & 750000 \\
\hline
\end{tabular}


The total estimated cost of organizing a business for the processing of wild plants is 750 thousand rubles, including:

- investments in fixed assets and design work - 550 thousand rubles;

- investments in working capital - 40 thousand rubles.

Projects are supposed to be financed from two main sources of funds:

- funds in the amount of 500 thousand rubles, which can be attracted within the framework of grant support;

- own financing in the amount of 200 thousand rubles.

If the amount of own investments is much less or more, then problems arise in obtaining additional grant funds.

A registered owner is required, one person is enough. As a result of the implementation of a business for processing wild plants using microwave vacuum drying technology, on average, 3 full-time workplaces are created (Table 2).

Table 2. Average need for personnel for organizing the business of harvesting and processing of wild plants.

\begin{tabular}{|l|l|}
\hline $\begin{array}{l}\text { Employee position } \\
\text { / Number, people }\end{array}$ & \multicolumn{1}{c|}{ Salary } \\
\hline Head -Owner / 1 & $\begin{array}{l}\text { Due to the fact that the activity of the head is year-round, the salary has a fixed } \\
\text { part and can be supplemented by a bonus part (depending on the availability of } \\
\text { the bonus fund, its volume, performance results, etc.) }\end{array}$ \\
\hline Dryer operator $/ 1$ & $\begin{array}{l}\text { Consists of a guaranteed salary and a bonus, depending on the volume of } \\
\text { production, because the work of an employee directly depends on the workload } \\
\text { of the equipment }\end{array}$ \\
\hline $\begin{array}{l}\text { Packing operator } \\
1\end{array}$
\end{tabular}

In addition to the employees hired to work in the organization, outsourcing costs must be taken into account to support other business processes. In this model, the calculation of personnel costs was made in terms of the transfer of the implementation of the accounting and equipment maintenance functions. The main argument in favor of outsourcing these processes is the optimization of labor costs in terms of transferring insurance contributions to social funds. In addition, by establishing contractual relationships with specialists of the required profile, the enterprise relieves itself of the duty of a tax agent in terms of transferring personal income tax (Table 3).

Table 3. Qualification requirements for employees.

\begin{tabular}{|c|c|c|c|}
\hline Position & Education & Qualities required & $\begin{array}{c}\text { Work } \\
\text { experience }\end{array}$ \\
\hline Head & Higher & $\begin{array}{l}\text { honesty, decency, conscientiousness, good } \\
\text { knowledge of the computer, ability to manage }\end{array}$ & $\begin{array}{l}\text { At least } 1 \\
\text { year }\end{array}$ \\
\hline Dryer operator & $\begin{array}{l}\text { Vocational } \\
\text { secondary }\end{array}$ & $\begin{array}{l}\text { honesty, decency, conscientiousness, } \\
\text { knowledge of the technological process, } \\
\text { computer skills }\end{array}$ & $\begin{array}{l}\text { At least } 1 \\
\text { year }\end{array}$ \\
\hline Packing operator & $\begin{array}{l}\text { Vocational } \\
\text { secondary }\end{array}$ & $\begin{array}{l}\text { honesty, decency, conscientiousness, } \\
\text { knowledge of the technological process, } \\
\text { computer skills }\end{array}$ & $\begin{array}{l}\text { At least } 1 \\
\text { year }\end{array}$ \\
\hline
\end{tabular}

An enterprise with a simultaneous parallel processing of various raw materials (for example, drying of wild plants and packaging of finished products) requires a larger number of employees. At the same time, in some cases, the same personnel in different seasons can work in different areas.

The bulk of the personnel will be seasonal workers, whose wages will be paid only 
during the period of their main activity under the piecework wage system.

Next, the costs are determined (a list of fixed assets with an indication of the cost for each unit, rent calculation) for organizing a business (Table 4)

Table 4. Composition and average cost of organizing a business for the harvesting and processing of wild plants (data of 2020).

\begin{tabular}{|l|l|}
\hline Type of expenses & Amount, rub. \\
\hline Microwave vacuum drying plant of the series "Monsoon" & 550000 \\
\hline Vacuum packing machine & 10000 \\
\hline Certification & 50000 \\
\hline Rent & $\begin{array}{l}60000\left(5 \text { thousand rubles } / \mathrm{month}^{*} 12\right. \\
\text { months })\end{array}$ \\
\hline Warehouse equipment & 20000 \\
\hline & $137000(2 \mathrm{kWh} * 12,500 \mathrm{~kg} * 3 \mathrm{~h} *$ \\
& $\begin{array}{l}3.34) \\
3 \mathrm{~h}-\text { average operating time of the } \\
\text { dryer, } \\
2 \mathrm{kWh} / \mathrm{kg} \mathrm{-} \mathrm{average} \mathrm{energy} \\
\text { consumption of the dryer, } \\
3,34-\text { coefficient of conversion of } \\
\text { green raw materials, } \\
12500-\text { final dry product }\end{array}$ \\
Cost of the technological process of drying wild plants & 40000 \\
& 20000 \\
\hline $\begin{array}{l}\text { Other expenses (packing materials, containers, special } \\
\text { clothing, stationery, communications) }\end{array}$ & \\
\hline Brand development and marketing strategy & \\
\hline
\end{tabular}

The cost of the purchased equipment includes the total set of costs for the acquisition, installation, and adjustment of equipment, i.e. bringing it to full operation - "ready-tooperate". Due to the fact that production involves the creation of a full cycle from independent harvesting (collection of wild plants) and subsequent processing, bringing to the sale of processed products of wild plants to end consumers, there is a need to purchase a vacuum packer.

In the process of processing wild plants, it is permissible and quite rational to use the functional zoning of the rented production facility. This event will save money on the rental of additional premises, reduce the labor intensity of staff, by saving time [8; 13].

In addition to the economic feasibility of zoning, it is necessary to take into account the fact that the risk of contamination of raw materials, materials, semi-finished products and finished products cannot be excluded in the production process. In this connection, the production workshop must be divided into the following functional zones "clean" and "dirty", "wet" and "dry".

In this connection, the composition and amount of expenses includes the costs of equipping the premises: division into zones, creation of a rack system, technological passages, wiring.

Other expenses include: packing materials for packaging finished products (paper souvenir and birch bark packaging, polymer metallized vacuum packaging), containers, special clothing, stationery, communication services.

Having determined the expenditure components of the business, then the income component is determined on the basis of average retail prices for products (Table 5). 
Table 5. Planning product prices

\begin{tabular}{|c|c|}
\hline Product & Input parameters \\
\hline \multicolumn{2}{|l|}{ MUSHROOMS dried, units $-\mathrm{kg}$} \\
\hline Porcini mushrooms 1 grade & 3500.00 rub. \\
\hline Porcini mushrooms 2 grade & 2500.00 rub. \\
\hline Aspen boletus & 1700.00 rub. \\
\hline Boletus & 2000.00 rub. \\
\hline Chanterelle & 2200.00 rub. \\
\hline Butterlets & $1800.00 \mathrm{rub}$. \\
\hline Honey mushrooms & 1200.00 rub. \\
\hline \multicolumn{2}{|l|}{ BERRIES, units $-\mathrm{kg}$} \\
\hline Blueberries (dried) & 1300.00 rub. \\
\hline Lingonberry (dried) & 1350.00 rub. \\
\hline Dried strawberries (wild) without stalks & 3000.00 rub. \\
\hline Hackberry (dried) & 450.00 rub. \\
\hline Rowan tree berries (dried) & $300.00 \mathrm{rub}$. \\
\hline Siberian rosehip & $230.00 \mathrm{rub}$. \\
\hline Hawthorn "red" fruit & 250.00 rub. \\
\hline Viburnum fruits (dried) & 380.00 rub. \\
\hline Dried buckthornberry (vacuum drying) & 1200.00 rub. \\
\hline Herbal mixture for bath steamers (phyto-collections, assorted) units $-\mathrm{g}$ & $\begin{array}{l}30 \text { g. }-30 \text { rub.|pc. } \\
50 \text { g. }-50 \text { rub. } \backslash \text { pc. } \\
100 \text { g. }-95 \text { rub. } \mid \text { pc. } \\
300 \text { g. }-250 \text { rub.|pc. } \\
500 \text { g. }-400 \text { rub. } \mid \text { pc. }\end{array}$ \\
\hline Siberian herbs (oregano, thyme, St. John's wort, tansy, etc.) & $\begin{array}{l}\text { units }-\mathrm{kg} \\
50.00-2000.00 \mathrm{rub} .\end{array}$ \\
\hline
\end{tabular}
Reference: [3].

The presented prices for manufactured products are average market prices prevailing on the wild plants market in Siberia. Note that the price of food products is free and unregulated, depending on demand and market conditions [6].

Further, proceeding from the prices, the volume of sales was determined (Table 6).

Table 6. Forecasted sales volume (units).

\begin{tabular}{|l|c|}
\hline \multicolumn{1}{|c|}{ Product } & Quantity, kg/year \\
\hline Dried berry & 2500 \\
\hline Dried mushrooms & 1250 \\
\hline Herbs & 2500 \\
\hline Total: & 6250 \\
\hline
\end{tabular}

The quantitative data of the forecasted sales volume is determined by the minimum volume of production and subsequent sales in order to ensure a break-even business for the processing of wild plants, i.e. production volumes correspond to sales volumes. The real conditions are such that in good years it is possible to increase the volume of production by at least 2 times.

Based on prices and quantities, the amount of sales was determined (Table 7). 
Table 7. Forecasted amounts of proceeds from sales (thousand rubles).

\begin{tabular}{|l|c|}
\hline \multicolumn{1}{|c|}{ Product } & Annual sales, thousand rubles \\
\hline Dried berry & 2250 \\
\hline Dried mushrooms & 600 \\
\hline Herbs & 1850 \\
\hline Total: & 4700 \\
\hline
\end{tabular}

Sales proceeds are calculated based on the sales price of the product. The prices for the products are set taking into account the prevailing prices on the market of wild plants in Siberia (Tomsk Region, Novosibirsk Region, and Altai Territory). In accordance with the marketing strategy (ensuring the competitiveness of goods), it is permissible to reduce the price of manufactured products by $10-15 \%$ below the market average $[2 ; 7 ; 14]$.

\section{Discussions}

The profitability of organizing a wild plant processing business is a determining factor. In a market economy, the goal setting of any commercial enterprise is profit and its growth while minimizing costs. A steady growth in the results of financial activities is the basis for the development of the enterprise, the expansion of the scale of its activities, and the strengthening of competitive positions.

The following is the calculation of the expected result from the implementation of the business (Table 8 ).

Table 8. Forecast calculation of the expected profit from the organization of a wild plant processing business.

\begin{tabular}{|l|c|}
\hline \multicolumn{1}{|c|}{ Indicator } & Values \\
\hline Net profit, thousand rubles & 487 \\
\hline Return on sales, \% & 10,4 \\
\hline Payback of subsidies, months & 13 \\
\hline Budgetary payback, months & 17 \\
\hline Social efficiency of the project, workplaces & 3 \\
\hline
\end{tabular}

As a result of the calculations, it was determined that according to the results of the forecast period, the business will receive a net profit of 487 thousand rubles, while the return on sales will be $10.4 \%$. The total payback of the received subsidy is 13 months, the budget payback is 17 months, and the social efficiency of the project is manifested in the creation of new jobs in the amount of 3 units.

A forecast sales plan is a kind of a specific program of activities aimed at selling finished products.

In the process of forecasting the sales plan, a research method of expert judgment based on knowledge and entrepreneurial experience was used (Table 9).

Table 9. Annual forecast sales plan, thousand rubles.

\begin{tabular}{|c|c|c|c|c|c|c|c|c|c|c|c|}
\hline \multirow{2}{*}{ Type of products } & \multicolumn{10}{|c|}{ Month } & \multirow{2}{*}{ Year } \\
\hline & 3 & 4 & 5 & 6 & 7 & 8 & 9 & 10 & 11 & 12 & \\
\hline Dried berry & \multirow{2}{*}{\multicolumn{3}{|c|}{ Preparatory stage }} & 75 & 225 & 425 & 525 & 450 & 300 & 250 & 2250 \\
\hline Dried mushro & & & & 50 & 100 & 100 & 100 & 100 & 100 & 50 & 600 \\
\hline Herbs & & & 50 & 100 & 500 & 650 & 750 & 600 & 550 & 500 & 1850 \\
\hline Total: & & & 50 & 225 & 825 & 1175 & 1375 & 1150 & 950 & 800 & 4700 \\
\hline
\end{tabular}


At the initial stage of business organization, the acquisition, transportation, installation, adjustment of equipment, preparation of the rented premises, its zoning, conclusion of contracts for the sale of finished products, continuous search for potential sales markets will be carried out $[2 ; 13 ; 15]$.

With the beginning of the spring-summer period, work begins related to the purchase of raw materials for subsequent processing, using equipment - microwave vacuum drying.

Thus, throughout the entire forecast period, the proceeds from sales for all types of products will be 4,700 thousand rubles.

The most affordable way to reduce the cost of paying taxes for persons engaged in the procurement and processing of wild-growing raw materials is to use the taxation system for agricultural producers (unified agricultural tax - UAT [4]).

At the initial stage of determining tax payments to budgets of different levels, the cost of production was predicted (Table 10).

Table 10. Forecast cost of production in 2021, thousand rubles.

\begin{tabular}{|l|c|}
\hline \multicolumn{1}{|c|}{ Indicator } & 2021 год \\
\hline Purchase cost of products, total, including: & 1700 \\
\hline berry & 750 \\
\hline mushrooms & 200 \\
\hline herbs & 750 \\
\hline Cost of the technological process of drying raw materials & 137 \\
\hline Equipment acquisition and installation costs & 550 \\
\hline Remuneration for labor with deductions & 1410 \\
\hline Premises for rent & 60 \\
\hline Material costs & 150 \\
\hline Other expenses TOTAL & 125 \\
\hline & $\mathbf{4 1 8 2}$ \\
\hline
\end{tabular}

Thus, the purchase cost of raw materials by type of product: berries, mushrooms and herbs will be 750,200 and 750 thousand rubles, respectively. The costs for the technological process of drying will amount to 137 thousand rubles. The forecasted total costs of personnel remuneration, including deductions, will amount to 4182 thousand rubles

The calculations made it possible to predict the final financial results of activities and calculate the amount of tax payments (Table 11).

Table 11. Forecast calculation of financial results and tax payments for 2021, thousand rubles.

\begin{tabular}{|c|c|c|c|}
\hline Tax type & Tax base & $\begin{array}{c}\text { Tax } \\
\text { rate, } \%\end{array}$ & $\begin{array}{c}\text { Tax amount per year, } \\
\text { thousand rubles }\end{array}$ \\
\hline $\begin{array}{c}\text { Contributions to extrabudgetary funds } \\
\text { (pension fund, compulsory health insurance } \\
\text { fund, social insurance fund) }\end{array}$ & 1085 & 30 & 325 \\
\hline SAT value & $\begin{array}{c}4700- \\
4182=518\end{array}$ & 6 & 31 \\
\hline Total tax payments & 356 \\
\hline Net income & 487 \\
\hline
\end{tabular}

It is necessary to take into account that in addition to taxes paid by a legal entity as a tax agent (tax on personal income) and tax deductions from the wage fund, it is necessary to take into account the amount of payments under the special tax regime (SAT - Single Agricultural Tax) with a tax base "income-expenses" and a tax rate of 6\% [4]. 
Consequently, the total amount of tax revenues to the budgets of different levels will amount to 356 thousand rubles.

\section{Conclusions}

The presented calculations allow drawing the following conclusions:

1. The process approach to organizing a wild plant processing business requires significant initial financial resources;

2. Even in the first season, income from the business commercialization allows recovering capital investments and operating expenses for the first year of implementation;

3. Subsidy payback and budgetary payback "come" in the second season of business implementation;

4. Despite the pronounced seasonality of income generation, the business organization for the integrated processing of wild-growing raw materials can reduce the risks of crop failure for each individual species of wild plants;

5. Organization of a business for processing wild plants allows creating more jobs, attracting seasonal workers (rural residents) in an amount of at least 250 people;

6. There is an opportunity to saturate the market of the Kemerovo region with natural, environmentally friendly products of healthy food.

\section{References}

1. T. G. Skurikhina, Business model of organization the complex harvesting of wildgrowing raw materials in the territory of the Tomsk region: study guide, 134 (2015)

2. A. Osterwalder, I. Pigne, Building business models: Handbook of the strategist and innovator, 288 (2011)

3. Internet portal: Russian agro-industrial server Agroserver.ru, www.AgroServer.ru

4. Tax Code of the Russian Federation (part two), 117-FZ (2000)

5. V. Kolerova, Business magazine, 3(239) (2016)

6. A. A. Stepanova, Agriculture, 1, 33 (2020) https://nbpublish.com

7. L. Argote, P. Ingram, Organizational Behavior and Human Decision Processes, 82(1), $150(2020)$

8. M. Aurisicchio, A. Z. Van Der Laan, M. Tennant, Sustainable Production, Life Cycle Engineering and Management, 89 (2021)

9. M. Dewi, I. N. P. Aryantha, M. Kandar, International Journal of Recent Technology and Engineering, 8(2), 81 (2019)

10. Y. Dogan, I. Ugulu, N. Durkan, Pakistan Journal of Botany, 45 (SPL.ISS), 177 (2013)

11. F. Fusté-Forné, Tourism Geographies (2019)

12. R. Karousou, S. Deirmentzoglou, Journal of Ethnopharmacology, 133(1), 191 (2011)

13. C. M. Lopes, A. Scavarda, L. F. Hofmeister, A. M. T. Thomé, G. L. R. Vaccaro, Journal of Cleaner Production, 1(142), 476 (2017)

14. Ł. Łuczaj, V. Lamxay, K. Tongchan, K. Xayphakatsa, K. Phimmakong, S. Radavanh, V. Kanyasone, M. Pietras, M. Karbarz, Journal of Ethnobiology and Ethnomedicine, 17(1) (2021)

15. L. Pereira, J. Santos, Á. Dias, R. Costa, International Journal of Knowledge Management, 17(1), 1 (2021) 